\title{
Metapoesía y niveles enunciativos en Jenaro Talens
}

\section{Metapoetry and Enunciative Levels in Jenaro Talens}

\author{
José Manuel Trabado Cabado \\ Universidad de León
}

\section{RESUMEN}

El objetivo de este trabajo es estudiar cómo funciona la enunciación metapoética dentro de la obra poética de Jenaro Talens. Se centra sobre todo en el análisis de textos como «Espacio del poema» y «Método del discurso». En ambos casos se crean una serie de instrucciones de lectura que nos obligan a pensar en varios niveles enunciativos. Mientras que la enunciación lírica puede decirse que «significa», el nivel metapoético «comunica». Podrían entenderse así, siguiendo la terminología de Sperber y Wilson, como una suerte de «ostensión»* encaminada a crear una «inferencia»* en el lector. Se perfila así una enunciación poliédrica en la que se alternan un «yo» lírico con un «yo» crítico que sirven como transición entre la supuesta ficción literaria y un pensamiento teórico que pertenece al autor real.

Palabras Clave: Enunciación metapoética; niveles discursivos; pragmática.

\section{ABSTRACT}

The aim of this paper is the study of metapoetic enunciation in Jenaro Talens' poetry. The paper focuses on the analysis of texts such as «Espacio del Poema» y «Método del Discurso». In both instances, a series of reading instructions come into being, which have to be thought of on different enunciative levels. While we could say that lyrical enuciation «means», the metapoetical level «communicates». Therefore, following Sperber and Wilson's terminology, they could be understood as sort of «ostention» aimed at creating an inference in the reader. Thus, a polyhedric enunciation is created between a lyrical «I» and a critical «I», which are useful as a transition between the alleged literary fiction and a Theoretical thought that belongs to the real author.

Key words: Metapoetical Enunciation; Discourse Levels; Pragmatics.

Múltiples han sido los intentos por aquilatar la esencia de la literatura y, cómo no, de la lírica. Si desde Aristóteles se ha venido incidiendo en el carácter ficticio de toda muestra literaria (se desdeña el criterio formal del verso, por ejemplo), no ha sucedido lo mismo con la lírica ${ }^{1}$. Su tardía aclimatación en el cam-

\footnotetext{
${ }^{1}$ Para una visión del problema de la ficción desde distintos puntos de vista puede verse el trabajo de Jesús G. Maestro (2006).

Copyright: (C) 2016 CSIC. Este es un artículo de acceso abierto distribuido bajo los términos de una licencia de uso y distribución Creative Commons Attribution (CC-by) España 3.0.
} 
po genérico no tiene lugar hasta la segunda mitad del XVI y en España habrá que esperar a la poética de Cascales para ver con claridad la definición de la lírica como un género más (García Berrio, 1975: 369 y ss; Génette, 1993:11-34; Guerrero, 1995 y 1998). Una de las razones que se ha aducido es la posible carencia del elemento ficticio dentro del terreno de la lírica. Sin embargo, y aunque esto ha sido visto por autores tan supuestamente biográficos como Lope de Vega, las propuestas actuales van más bien encaminadas a intentar mostrar cómo la lírica conlleva igualmente en su esencia un germen de ficción ${ }^{2}$.

Han sido sobre todo las propuestas pragmáticas aquellas que se han mostrado más efectivas a la hora de caracterizar la lírica como una forma de producción textual que se diferenciaría por una serie de peculiaridades dentro del sistema enunciativo. Una característica sobre la que se ha venido incidiendo sobremanera es la indeterminación contextual de la lírica. No se sabe quién enuncia el poema ni en qué situación espacio-temporal lo hace ${ }^{3}$. Esta indeterminación contextual provoca que el lector actúe rellenando esos huecos, que acabe asumiendo y proyectando de alguna manera su propio contexto sobre la indeterminación del poema hasta tal punto de llegar a apropiárselo ${ }^{4}$. Todo ello vendría también condicionado por el «yo» lírico que, lejos de verse como representante del autor real, se ha reconducido para verse como una estrategia textual que pierde su referencia externa, por un lado, y que, por otro, invita a la asunción vital del poema por parte del lector.

Con todo ello se puede concluir que el «yo» lírico actúa como un mecanismo distanciador entre el autor real y su poema. Se aduce que ese «yo» se

\footnotetext{
${ }^{2}$ En el panorama poético español actual existen tendencias divergentes que tienen incluso una concepción poética diferente. Esto atañe incluso al problema de la ficcionalidad. De un lado está lo que se ha denominado «poesía de la experiencia» que ve en el «yo» lírico un personaje y que acaba entendiendo en consecuencia la poesía como un tipo de ficción más. Véanse para el caso de Luis García Montero las páginas que le dedica Laura Scarano a la «Escenificación ficcional del yo» en su ensayo Las palabras preguntan por su casa (2004: 151-217). Por otro lado se le pueden contraponer las ideas teóricas de Antonio Gamoneda, que concibe la poesía como un discurso que no participa de la ficción y que se desmarca de lo que se entiende por literatura. Aunque no centrado en este asunto exclusivamente pero interesante por la creación de un panorama de amplio espectro de la poesía española actual, véase también el trabajo de Luis Bagué Quílez (2006). También puede verse el trabajo de Susana Díaz (2006: 40 y ss) en el que se sitúa la poética de Talens con respecto a la obra e ideas de García Montero. Por supuesto para una delimitación de la poética de Talens también resultan esclarecedoras las conversaciones de éste compiladas también por Susana Díaz bajo el título, Negociaciones para una poética dialógica. (Talens, 2002).

${ }^{3}$ Son de interés los trabajos de Pozuelo Yvancos (1998:55), también el de Ursula Oomen y el de Arturo Casas (1994). Para un estudio desde la pragmática de lo problemático del poema lírico puede leerse también el trabajo de Luján Atienza (2005). Para las operaciones de lectura asociadas a la lírica puede verse Trabado Cabado (2002).

${ }^{4}$ Así se expresa Lázaro Carreter: «La fuerza ilocutiva de una poesía es siempre una invitación al lector a que asuma el mensaje como propio» (1990a: 22). En otro lugar también Lárazo Carreter ha hablado de los efectos perlocutivos del poema (1990b: 42).
} 
convierte en un ser ficticio, inmerso en un mundo literario. Leer el poema como si fuese una declaración autobiográfica, se arguye, sería confundir a un ser real (el autor) con un ser ficticio (el protagonista de sus versos); confusión que, por otra parte, parece lógica si se atiende al hecho de que el sujeto de la enunciación y el sujeto del enunciado podrían enmascararse bajo un mismo pronombre 5 .

Sin embargo, todo este carácter confesional de la lírica queda en entredicho cuando se observa una divergencia entre el sujeto de la enunciación y el sujeto del enunciado. Podría verse como una tendencia relativamente reciente aquella que lleva al poeta a delegar la enunciación de su poema en un personaje bien histórico, bien fingido. De este modo se introducía una mediación entre el autor real y su mensaje lírico. De esta manera obraron poetas como Robert Browning cuya técnica del monólogo dramático ha sido estudiada por R. Langbaum (1996) y tanto ha influido en poetas como Ezra Pound o Luis Cernuda. No obstante, no resulta esto una novedad absoluta. A este respecto me gustaría recordar la figura de Lope de Vega, capaz de crear un personaje - Tomé de Burguillos - que habrá de falsificar la voz del propio Lope al tiempo que desentraña multitud de convenciones sobre las que se asentaba el sistema lírico petrarquista. Ciertamente se estaría ante un recurso no muy lejano de la ironía, característica que se ha visto como un rasgo esencial en la poesía postmoderna ${ }^{6}$.

La pregunta que a estas alturas cabe hacerse es la siguiente: ante la remodelación de la indeterminación contextual del poema ¿se puede observar un cambio en las actitudes lectoras? En cierta manera así ocurre ya que al asignarle a un personaje el peso enunciativo se crea una serie de barreras en la apropiación emocional por parte del lector del discurso lírico. Evidentemente, aún es posible la identificación del lector con el personaje que protagoniza ese poema de la misma manera que sucede con determinados protagonistas de una novela o de una obra de teatro. Sin embargo, el poema ha dejado de estar en tierra de nadie para pertenecer a un personaje y su circunstancia. El lector

${ }^{5}$ La bibliografía sobre todo el problema del «yo» es amplia pero me gustaría destacar el trabajo de Carlos Piera (1995). Se ha puesto en relación la idea de ese «yo» lírico ficticio con la escritura propia de la autoficción (Lucifora, 2013). En relación con el problema del «yo» narrativo remito al estudio de Pozuelo Yvancos que, aunque centrado en la obra de Javier Marías y Enrique Vila Matas, supone una sólida reflexión sobre el asunto (Pozuelo Yvancos, 2010). Asimismo debería completarse con la importante antología de textos sobre la autoficción realizada por Ana Casas (2012) en la que existe una extensa bibliografía sobre el asunto.

${ }^{6}$ Así escribe Pere Ballart: «La ironía, por consiguiente, hace en la poesía moderna las veces de un regulador de excesos tanto ideológicos como sentimentales en que puede incurrir el poeta. Su rotundidad en el juicio, su efusión en la expresión de íntimas emociones deben ser amortiguados por la acción desengañada de unos modos de dicción que aseguren que la adhesión del sujeto poético a lo que dice es circunstancial y cuestionada por su mismo enunciador» (1994: 380). Para una profundización en la vinculación entre la poesía contemporánea y la ironía remito a los artículos de Luis Bagué Quílez y Susana Rodríguez Rosique (2012 y 2013). 
habrá de someter su actividad lectora al tamiz que forma la concreción situacional del poema; es decir, algo tendrá que haber en ese personaje y su circunstancia que suscite la posibilidad de una empatía emocional debido a que el «yo» lírico ha desaparecido en cuanto que mecanismo de proyección del lector sobre el poema o del poema sobre el autor real.

Como consecuencia de todo ello surge la necesidad de un replanteamiento de la ontología del discurso lírico. El lector puede llegar a pensar que ese mismo «yo» lírico que suele monopolizar la actividad poética puede ser también una máscara bajo la cual el autor se esconde y a través de la cual diversifica y hace legible su propia experiencia vital. Desde este momento todo discurso lírico, incluso el que presenta un mayor atisbo de confesionalidad, está bajo sospecha. Se puede tratar de un texto que se estructura a modo de discurso autobiográfico pero este hecho no deja de ser una ilusión.

Desde un punto de vista semántico la lírica se ha visto como una desviación o un uso anómalo de la lengua estándar. Frente al carácter denotativo de la lengua estándar, la lírica se basaría en el carácter connotativo. Ciertamente se está ante el uso figurado de la lengua que tiene sus raíces en una concepción retórica de la literatura? ${ }^{7}$.

Una vez que se ha intentado un acercamiento desde un punto de vista semántico y pragmático a la esencia de la lírica -a saber, la lírica es un género literario ¿igualmente ficticio? y que además se basa en una serie de anomalías semánticas que indican ciertas irregularidades en la referencia del signo poético- cabría preguntarse si todo esto sucede igualmente con lo que se ha denominado «metapoesía».

La primera hipótesis, efectivamente, podría hacernos pensar que la metapoesía comparte todas las características de la poesía sólo que, además, se añade un rasgo nuevo: la capacidad que el discurso lírico tiene de referirse a sí mismo. A mi juicio, podría llegarse por este camino a una contradicción: si todo el poema parte de ser algo ficticio, cómo prestar crédito a una parte del poema que se constituye como una especie de poética o, dicho de otra manera, cómo en un mismo marco discursivo se pueden observar elementos ficticios y otros que cobran visos de presentar toda la apariencia de funcionar al margen del régimen ficcional. Se puede llegar a una aporía en la que se vea que el discurso metapoético habla de la falsedad del discurso poético pero se integra dentro de este mismo.

Otra hipótesis podría pasar por considerar que en determinados poemas se está ante un mismo espacio textual pero con distintos niveles enunciativos. Se crearía así una suerte de jerarquía en la enunciación lírica en la que determinados asertos tienen la capacidad de modificar la percepción del poema o del

\footnotetext{
${ }^{7}$ Para un repaso de las anomalías semánticas véase Salvador Gutiérrez Ordóñez (1996: 145-158). También se ocupa en ese mismo lugar de la connotación (1996: 71-82). Sobre la connotación también pueden leerse las páginas que le dedica Pozuelo Yvancos (1994:52-61).
} 
resto de poemas. Podría entenderse entonces que la literatura hace legible la experiencia y la metaliteratura hace legible la propia literatura, es decir, muestra las reglas de funcionamiento de lo literario.

De esta manera la metapoesía se conforma como un conglomerado de instrucciones que operan sobre el proceso lector y esto es así gracias a su naturaleza híbrida que le lleva a asumir rasgos del discurso teórico y crítico desplazando así el protagonismo que posee la metáfora en cuanto que desviación semántica de la lengua estándar. A la vez, este carácter unívoco en su semántica opta por formalizarse dentro de los cauces métricos habituales del discurso lírico. Incluso, contextualmente, el lector tiende a considerarlo también como parte del poemario. El «yo» del poema, lejos de representar al autor real dentro de su propia creación, se convierte en una entidad poliédrica capaz de encarnar distintas actitudes del autor real. Si el protagonismo de la enunciación lírica recae sobre el «уо» lírico — que es ficticio, producto literario—, la enunciación metapoética será encarnada por un «yo» crítico que desde un punto de vista lector está mucho más cercano al autor real e incluso podría acabar por fundirse con él ${ }^{8}$.

Las interpretaciones que ven en la metapoesía un tipo de lírica que es igualmente ficticia acaban, en definitiva, por privilegiar determinados niveles semiológicos como pueden ser aquellos que operan en el substrato prosódico: el mismo hecho de que la mayor parte de la metapoesía se encuentre escrita en verso lleva a considerar que este tipo de expresión es igualmente ficticia ${ }^{9}$. Sin embargo, si todo metapoema es en definitiva un texto lírico habría que admitir que perdería su capacidad referencial y su esencia crítica sería sólo un espejismo $^{10}$. Mi lectura opera más bien en un sentido diferente, al menos para el caso de la poesía de Jenaro Talens.

\footnotetext{
${ }^{8}$ Resulta curioso comprobar cómo los poemas en los que se centran estas páginas muestran una acusada impersonalidad. Véase para ello lo que Lozano et alii denominan como cancelación del sujeto en textos teóricos y científicos (1982: 119).

${ }^{9}$ Estas son las ideas de Leopoldo Sánchez Torre en su, por otra parte sugerente, estudio sobre la metapoesía. Sánchez Torre, tras describir la tensión entre lenguaje crítico y lenguaje poético existente en todo metapoema, acaba por privilegiar el substrato poético sobre el crítico: «Pero no debe olvidarse que el lenguaje del metapoema es siempre lenguaje poético. Ocurre que el lenguaje teórico que entra en tensión con el poético, o la tensión misma, se semantiza, esto es, se transfiere a lo que Lotman llamaría el nivel secundario (...) El lenguaje teórico, que funciona como un sistema de modelización primario, cuando pasa al poema se integra en el sistema de modelización secundario que es el poema.» (1993: 99). Puede verse también un repaso por extenso sobre la metaliteratura y la ficción en Pérez Parejo (2002: 113170 y 2007). Un análisis específico de la metapoesía de Talens lo lleva a cabo Ewa Smilek en su tesis de doctorado leída en la Universidad de Silesia (2013). Todo ello puede complementarse con las páginas que dedica Martín-Estudillo a la importancia de la metapoesía en la generación poética de los 70 (2007: 157-185).

${ }^{10}$ En otras ocasiones Sánchez Torre destaca los distintos niveles en los que opera el texto y el metatexto: «El metatexto se configura, pues, desde la perspectiva de la Retórica, como una violación del orden natural, como una ruptura de las reglas textuales que, como ya dijimos, se traduce en la creación de un nuevo código textual» (1993: 55)
} 
Sostengo que no todo opera a un mismo nivel pragmático. Si se ha demostrado que el discurso lírico es parte también de la ficción literaria y que todo metapoema es un discurso lírico con apariencia de discurso crítico-teórico, la estrategia que se ha utilizado es la apuesta decidida por inclinar el fiel de la balanza de la tensión de todo metapoema a favor del elemento literario. Cabría preguntarse si dicha opción no tendrá en cuenta, por un lado, la primacía de lo formal sobre cualquier otro nivel y, por otro, si no se estará utilizando un criterio semántico demasiado coercitivo; todo lo que forma parte de un poemario es literatura: es ficción. Quizás en la época postmoderna en que todo se halla fragmentado y existe una tendencia a la descomposición sería mejor no utilizar determinados criterios apriorísticos y pensar que, cada vez más, la literatura y otras formas discursivas - la misma crítica literaria - se nutren de distintos códigos que conllevan distintas maneras de significar y que no se cancelan si entran en contacto.

Propongo en consecuencia la posibilidad de entender la metapoesía, al menos en la obra de Talens, como instancia enunciativa que, desde un punto de vista pragmático, opera en un nivel superior a la enunciación lírica con el fin de anular determinadas convenciones de ésta e instaurar otras. Se trata de lo que Sperber y Wilson ${ }^{11}$ definirían como una ostensión encaminada a provocar determinadas inferencias en el lector. Su naturaleza escapa a las convenciones ficticias del texto literario porque de suyo mantiene determinados registros, de índole semántica sobre todo, que se lo permiten ${ }^{12}$. Podría entenderse así que el hecho de que acabe por ahormarse siguiendo determinadas matrices formales típicas de la lírica sea, quizás, una estrategia de legitimación del discurso teórico que tiene como misión crear un horizonte de expectativas, forjar un contexto comunicativo en el que las reglas están ya pergeñadas $^{13}$. Y todo esto por qué. No es suficiente acaso la competencia genérica tanto del autor como del lector para interpretar lo que allí se dice en su justa medida. En el caso de Talens, acaso se sospeche que la tendencia a interpretar el discurso lírico de una forma confesional es todavía muy fuerte. De esta manera se reconducen las estrategias lectoras y se remodelan las claves de producción y recepción de la lírica pero de una forma explícita.

La indeterminación contextual de la lírica queda reducida en cierta manera. Existe ya una serie de reglas de producción e interpretación encaminadas a crear un lector implícito muy determinado: este lector implícito se construye sobre la remodelación de la idea romántica de la confesionalidad de la poesía.

\footnotetext{
${ }^{11}$ Para una aplicación de la teoría de la relevancia elaborada por Sperber y Wilson al estudio de la literatura puede ser de interés el trabajo de Adrian Pilkington (2000).

${ }^{12}$ Quizás resulte significativo destacar que ni «Espacio del poema» ni «Método del discurso» aparecen incluidos en la antología de la obra de Talens realizada por Juan Carlos Fernández Serrato para la editorial Cátedra.
} 
Por supuesto, esta regulación de orden pragmático sobre el discurso lírico posee ciertas características que acaban por determinar las coordenadas temáticas del propio discurso lírico: por ejemplo, la polifonía enunciativa que se cifra en la categoría de la máscara. Si todo es ficción, mi yo puede ser muchos, gracias a ellos también puedo sondearme mejor.

El poder de esta enunciación metapoética —encaminada a reconducir las expectativas lectoras - facilitará posteriormente la actividad hermenéutica del sustrato simbólico que agavilla las distintas metáforas en torno a una concepción acerca de lo que debe ser la poesía. Este papel lo asumen, por ejemplo, textos como «El espacio del poema» ${ }^{14}$, que se desembaraza de uno de los cauces de representación genérica tenidos por habituales: el verso.

Podría verse en él una suerte de guía de lectura del corpus lírico que a continuación sigue: la comparación del poema con un cuadro, imagen por otra parte sólidamente enraizada en la tradición poética clásica tal y como se puede ver en la obra de Neus Galí (1999), hará referencia sin duda a la pérdida del vínculo genético de la lírica que conecta autor-poema en una ecuación de identidad: «Una vida separada, definitivamente ya, de los concretos individuos que a diario aparentan (del otro lado de la tela) ser su centro emisor» escribe Talens en su compilación Cenizas del sentido (1989: 15).

Si se rompe la unión autor real-poema, sólo queda como protagonista del acto lírico una instancia lingüística, nada más: «Todos ellos son frases. Frases que nadie enuncia, nadie o ese producto de la convención, sin existencia previa, que llamamos sujeto: lo que uno (autor-actor) puede representar para quien mira (espectador-lector)» (Talens 1989: 16) ${ }^{15}$. La fictivización del discurso lírico, partiendo de una comparación cuadro-poema, acarrea una serie de consecuencias:

${ }^{13}$ Otro mecanismo de legitimación es la intertextualidad entre discurso metapoético y discurso poético. Las ostensiones del discurso metapoético no sólo afectan al campo semántico, sino que van más allá y acaban por poseer un carácter visual. El hecho de que el poema «Método del discurso» aparezca girado sobre el papel y obligue a detener la lectura es una señal de que ese texto está intencionalmente marcado. Estos mecanismos visuales funcionarían como la entonación o todos aquellos elementos del paralenguaje que en la vida cotidiana se semantizan. En la conversación normal el código gestual puede modificar el sentido de nuestras palabras; de igual manera sucede aquí: lo visual puede ser una estratagema más encaminada a modificar las convenciones de lectura. Véase el apéndice en el que se incluyen estos textos para apreciar las características tipográficas de esta escritura

${ }^{14}$ Sobre este poema léanse las páginas de Susana Díaz (2006: 81 y ss). A ello debe añadirse el texto de Carlos Jiménez Arribas (2007). «El espacio del poema» aparece incluido como prólogo al libro El vuelo excede el ala. (Talens 1989:13-15)

${ }^{15}$ Barthes afirma algo semejante cuando escribe en $S / Z$ : «Cuanto más difícil es detectar el origen de la enunciación, más plural es el texto. En el texto moderno las voces son tratadas hasta la negación de toda referencia: el discurso, o mejor aún, el lenguaje habla, y eso es todo.» (33). De igual manera pueden servir las siguientes palabras, también de Barthes que figuran en «La muerte del autor»: «La escritura es ese lugar neutro, compuesto, oblicuo, al que van a parar nuestro sujeto, el blanco-y-negro en donde acaba por perderse toda identidad, comenzando por la propia identidad del cuerpo que escribe.» (65) 
a) Ruptura entre el mundo real (autor) y el literario (el poema) según indica Pozuelo Yvancos (1999:181 y 186-187) ${ }^{16}$.

b) En consecuencia esta distancia insalvable hace que el sujeto del poema nada tenga de biográfico. Existe una transposición de lo emocional (lo esperable desde una perspectiva lectora) a lo lingüístico (nueva forma de entender la poesía).

c) Fruto de todo ello es la teatralización del discurso lírico: el binomio autor-lector se transforma en actor-espectador y el sujeto lírico no deja de ser una máscara o, mejor dicho, una serie de máscaras que derivan en una polifonía enunciativa, ajena en principio al discurso lírico ${ }^{17}$.

d) Esta transformación de lo vital en lingüístico, de lo confesional en teatral supone una aniquilación previa para un volver a nacer, no renovado sino distanciado de sí: «Transformación que es muerte y es renacimiento (escribo bien: renacimiento, que no resurrección: no el fénix que en la pira muere y nace» (Talens, 1989: 17) ${ }^{18}$.

De forma paralela otro texto trata de ejemplificar el proceso de creación. Dos voces simultáneas protagonizan aquí la enunciación metapoética, llegando incluso a establecer una simultaneidad espacial que impide una lectura

${ }^{16}$ Sobre la pérdida de la referencialidad del texto postmoderno escribe Alfredo Saldaña (1997:89-90): «El texto literario es ya un objeto artístico autorreferencial. El lenguaje, no sólo artístico o literario, experimenta desde mediados del siglo pasado un proceso aparentemente irreversible de pérdida de la capacidad para expresar de forma fiable y precisa la realidad, para representar el mundo de acuerdo a unas normas de conocimiento y de pensamiento socialmente admitidas.»

${ }^{17}$ La máscara tiene para Talens una gran importancia en el proceso de comunicación tal y como lo expresa en su artículo «Práctica crítica y reflexión metapoética»: «Yo planteaba el hecho de que solemos olvidar que lo que llamamos la comunicación es un intercambio de máscaras. Y las máscaras son eso: máscaras, que no permiten ver a su través. Sólo reflejan cosas. Y muchas veces no oímos lo que nos dicen, sino que oímos lo que nosotros lanzamos en el espejo que es el otro construido por nosotros». (1980:238). Por su parte Dominique Rabaté afirma: «La complexité des déplacements énonciatifs est donc au coeur du lyrisme; la poésie moderne a fait de la fragmentation de ces voix le champ même de son travail» (1996 :75). Tal es así que el carácter monológico no es para él, al contrario de lo que había dicho Bajtin, una característica fundamental de la lírica frente a la novela: «Je pense avoir sufissament montré en quoi l'enonciation lyrique est travaillé de fragments de voix, de leur croisement» (1996: 77). Conviene recordar aquí las ideas de Bajtin acerca del carácter monológico de la poesía: «La idea de los universos lingüísticos, igualmente significativos y expresivos, es orgánicamente inalcanzable para el estilo poético» (1989: 103). En otro lugar se afirma: «La unidad y la unicidad son condiciones indispensables para la realización de la individualidad intencional directa [...] del estilo poético y de su consecuencia como monólogo.» (1989: 104). Sobre el sujeto en la poesía de Talens remito al estudio de Pozuelo Yvancos (2007) y también los trabajos de Falcó (2007) y Trabado (2007).

${ }^{18}$ Así lo escribe Talens: «Disolución del yo, la pérdida (simbólica) de identidad (la muerte). La producción del texto como traducción (transformación) dentro del mismo espacio (textos)» (1989: 21) 
continua y lineal. Bien pudiera esta segunda voz funcionar a modo de prólogo cervantino. Ciertas resonancias quijotescas se pueden entrever, a mi juicio, en este texto. Interesa señalar que, aparte de repetir las afirmaciones expuestas por la otra voz u otro discurso que se desarrolla a la par, añade una serie de elementos intertextuales que luego volverán a aparecer en el corpus poético a modo de encabezados de algunos poemas ${ }^{19}$. De esta manera puede observarse una doble funcionalidad del sustrato intertextual:

a) Por un lado, mostrar la intertextualidad como procedimiento de motivación textual que anula la individualidad ${ }^{20}$. Escribir no es contar lo que sucede en el interior del poeta, sino transformar lo que otros han escrito. La escritura poética pierde su talante vital para incardinarse de lleno en lo intelectual. ${ }^{21}$

${ }^{19}$ Así, por ejemplo, se encuentran ejemplos como los siguientes: el intertexto cervantino: «para morir jamás le falta tiempo / al que quiere morir desesperado» (tomado de la tragedia Numancia, vv. 641-2 de la segunda jornada y puesto en boca del Cuarto Numantino) reaparece inmediatamente antes del poema «Desde la ventana» (Talens, 1989: 36); de igual manera sucede con la expresión «los cuerpos que trasmigro incoloran mi piel», que es una cita de uno de sus propios poemas: más en concreto es el verso segundo del poema «Ars poetica» (Talens, 1989: 141). La expresión «laberinto de espejos» es el inicio de otro poema «UBÅTSGATAN»: «Laberinto de espejos / sobre la superficie de los días» (Talens, 1989: 84). También existe otro lazo entre el poema «Ars poetica» y este metapoema prólogo «El espacio del poema»: se trata de la expresión «hilo indestructible».

${ }^{20}$ Convendría recordar algunas de las ideas del propio Jenaro Talens que sirven como marco para relacionar esa teatralidad textual con la intertextualidad como motor de generación de lo literario. Destaco estas palabras que pertenecen a su libro de ensayos de título bien significativo - La escritura como teatralidad - : «El escritor se sitúa en el lenguaje y no el lenguaje en el escritor. Para ello penetra en él pertrechado con los procedimientos que la tradición ofrece y que a él, en tanto individualidad diferenciada, le ofrece su grupo social [...] El escritor individualizado no hace más que introducirse en un mundo que le precede al tiempo que justifica su presencia en ese mundo por el hecho de reestructurar un imaginario colectivo, previo a su existencia como escritor, y cuyos elementos, ya elaborados y, en muchos casos, codificados, le imponen unos ciertos límites a su capacidad de movimiento.» (Talens 1977: 11).

${ }^{21}$ Significativo es el inicio del poema en prosa «El final del laberinto»: «El aislamiento de una música en medio de la tormenta no tiene más sentido que estas palabras irreconocibles que un náufrago pronuncia como suyas, aun ignorando a quién o quiénes pertenecen. Estériles esbozos para una teoría de la resurrección.» (Talens, 1989: 97). Puede encontrarse un parecido con estas palabras de Barthes que aparecen en su clásico «Muerte del autor»: «El escritor se limita a imitar un gesto siempre anterior, nunca original; el único poder que tiene es el de mezclar las escrituras, llevar la contraria a unas con otras, de manera que nunca se pueda apoyar en ellas; aunque quiera expresarse, al menos debería saber que la «cosa» interior que tiene la intención de «traducir» no es en sí misma más que un diccionario ya compuesto, en el que las palabras no pueden explicarse sino a través de otras palabras» (Barthes 1987: 65). Así pues, podría decirse que la intertextualidad tanto para Talens como para Barthes es un mecanismo para eliminar la individualidad y huir así de la idea de una poesía confesional. El escritor no puede sino citar otras escrituras. Otra consecuencia de no menos importancia es que tanto la escritura poética como el discurso crítico pueden encua- 
b) Por otro lado, la intertextualidad sirve como eslabón entre la enunciación metapoética y el resto del corpus lírico. Dicho de otra manera, supone una línea de permeabilización del discurso crítico en el lírico. Así el lector puede observar una serie de coherencias que le llevan a ver todo el entramado poético como un todo intencional y guiado, por tanto, por una necesidad comunicativa.

Otra función que desempeña el presente texto metapoético es la de anticipar la matriz temática sobre la que se va a sustentar el discurso poético. Sin embargo, esta anticipación no sólo posee una finalidad meramente proléptica, sino que se ofrece como una interpretación ya dada de los símbolos recurrentes que llevan implícita una tensión también metapoética.

Asociado al tema del cuadro-poema surge inevitablemente el símbolo arquetípico del espejo que refleja el original sin ser él. Es, al igual que un poema, un simulacro y, al igual que el poema, también provoca un conocimiento de sí mismo. En este sentido cabría situar el mito de Narciso, reinterpretado desde una óptica también metapoética ${ }^{22}$.

De esta última idea se desprende otra característica esencial en la obra poética de Jenaro Talens: la anulación de la temporalidad a favor de lo visual. Así escribe en el poema titulado: «La mirada del poeta»: «La eternidad no es más que una mirada / que el pensamiento fija». De igual manera en la parte III del poema «Faro Sacratif» se dice que:

Toda historia es ficción.

Y más aún: sólo como ficción la historia existe.

Porque no hay tiempo, sino realidad

que acomoda la luz en la memoria (Talens, 1989: 78) ${ }^{23}$.

De igual manera acaba el poema «Ceremonias»:

drarse bajo el marbete de metalenguajes puesto que ambos se refieren a una escritura anterior. Sobre la intertextualidad pueden verse los trabajos de Martínez Fernández (2001) y la interesante compilación de trabajos realizada por Desiderio Navarro (1997).

${ }^{22}$ Véase el poema de Jenaro Talens titulado: «Fabulación sobre fondo de espejo» (1989: 59) y también «Narciso» cuyos últimos versos rezan así: «Lo real eras tú, no estas rotas imágenes / que con su luz golpea / el sol. / Ahora tu sed, la sombra de las prolongaciones / ya no existen sin ti, / como tú, que no eras / sino la esterilidad de tu ficción». De una manera similar se había expresado Guillermo Carnero en su poema «Lección del agua» (1987: 307). Sobre la temática del espejo han tratado, por ejemplo, Prieto de Paula (1996: 223-244) y, en el caso de Leopoldo $\mathrm{M}^{\mathrm{a}}$ Panero, Túa Blesa (1987).

${ }^{23}$ En la parte IV son significativos los versos que siguen: «Es un jardín pequeño, / sin concreción de tiempo ni de espacio. / Sólo una luz: infancia. / Infancia, sí; pasado, / ese extraño país / donde todo sucede de manera distinta. / Ninguna flor persiste, / y, sin embargo, todas son, / pues que jamás acecha la caducidad / en el presente inmóvil / del existir, hasta que la memoria / los hechos reinventa y unifica. / Que el transcurso y el orden, / su sucesividad, / son materia simbólica, / y al final sólo queda / no el tiempo: su ficción.» (Talens, 1989: 79). 


\author{
$\mathrm{Y}$ asistimos al rito \\ de uncir el tiempo a las fotografías \\ para un nuevo espectáculo: \\ la ceremonia de la soledad ${ }^{24}$ (Talens, 1989: 91).
}

Se transforma así la memoria en una imagen, escena sin tiempo que no reproduce la realidad sino su simulacro, espectros de luz que habrán de ordenarse a modo de ficción. La palabra poética se convierte en un rostro en el que el poeta no se reconoce. Así lo escribe en el poema «Vidas paralelas»:

\author{
Ah, los rostros iguales, \\ las palabras que fueron \\ prolongación de mí \\ y hoy sin mí cruzan y me desconocen, \\ sortilegio en imágenes \\ sin pasado, presente ni futuro, \\ tumba de un sueño dulce \\ y una melancolía de papel (Talens 1989: 95)
}

Dejando a un lado la matriz temática que constituye el texto «El espacio del poema», es interesante atender al poema «Método del discurso» que inicia la sección titulada «La máquina de significar» del libro El cuerpo fragmentario. Ya el título se puede poner en relación con otro poema de Guillermo Carnero incluido en Variaciones y figuras sobre un tema de la Bruyère: «Discurso del método». Dos hechos fundamentales comparten ambos textos:

a) Ambos conforman una suerte de guía de lectura del poemario que encabezan. En el caso de Carnero se establece la diferencia entre variación y figura y, aparte, se establece una proclama sobre cómo entiende la poesía (Lanz, 1994: 106-107).

b) Ambos textos también adoptan un lenguaje pretendidamente críticocientífico que los desmarca de la dicción lírica.

Ambos factores provocan desde un punto de vista pragmático una anulación de las diferencias entre discurso crítico y poético: estos metapoemas tienen como objeto la poesía en general a la vez que crean unas expectativas lectoras que incidirán en la interpretación del resto de poemas. Para forzar esa lectura en cierto modo restrictiva, el lenguaje no tiene más remedio que volverse unívoco en su referencialidad ${ }^{25}$.

Si se toman estos poemas en el mismo nivel que los demás habría que admitir el establecimiento de un absurdo. Gana terreno, por consiguiente, la necesidad de plantear distintos niveles dentro del terreno lírico.

\footnotetext{
${ }^{24}$ Muy significativa son las palabras incluidas en el poema «El bosque se suicida»: «Imágenes tan sólo. Imágenes que narran una historia» (Talens, 1989: 91).

${ }^{25}$ Véanse las notas que al poema de Carnero le dedican tanto Kruger-Robbins (1997: 7880) y, más en profundidad, López (1986: 78-80).
} 
Se puede objetar que ambos poemas son ejemplos límite. Sin embargo, en el caso de Talens se pueden establecer parangones entre «Método del discurso» y el «Espacio del poema»:

- Ambos son prólogos a una colección de poemas, lo que desde un punto de vista estructural facilita la adquisición de valores metapoéticos.

- Ambos poemas tienden a una dicción que se asimila al discurso crítico y ambos comparten estrategias de lectura: la disposición textual no permite una lectura continua; en el caso de «El espacio del poema»se utilizan dos discursos en prosa que avanzan paralelos conformando dos columnas; en el «Método del discurso» se trata de un texto dispuesto en vertical y cruzado por citas de Nietzsche y Bretch en horizontal.

Ambos poemas tienen, además, un sustrato crítico explícito sustentado en la intertextualidad, bien implícita — como es la referencia a Celaya o Jakobson y su función poética (caso del «Método del discurso» ${ }^{26}$ )—, bien explícita como son las citas dispuestas en horizontal o su referencia al poema «El Arte del poema». Incluso puede verse cómo los mecanismos de disposición textual que atienden sobre todo al carácter de simultaneidad y enfatizan la faceta visual (no ha de olvidarse la conexión entre los conceptos cuadro/ tapiz / espejo /imagen / poema) son compartidos por otros poemas ${ }^{27}$.

Estos dos metapoemas son casos de metapoesía extrema que intentan regular las convenciones de interpretación de los poemas que les siguen. Se relacionan con ellos bien por medio de mecanismos formales (disposición textual), bien mediante la anticipación de la matriz temática, bien mediante referencias intertextuales.

\footnotetext{
${ }^{26}$ Algunas referencias están implícitas como: «la poesía es un arma sin futuro» en la que se rehace el famoso título del poema de Celaya (publicado en Cantos iberos) para desmantelar la función asignada a la poética de la poesía social. También se alude a Mallarmé en otro lugar: «algún golpe de dados finalmente abolido» o incluso al poeta italiano Antonio Porta compilado por Alfredo Giuliani en su Novisssimi. Poesie per gli anni 60 (Einaudi, 1961) que establece un fructífero diálogo con la antología de los Novísimos elaborada por José María Castellet. La inclusión de un verso de Antonio Porta «entrò nelle abitudini» del poema «Dialogo con Herz» establece una sintonía quizás no sólo textual sino programática en la concepción poética -véase para una panorama de la vanguardia italiana (Picchione 2004)-. Resulta curioso comprobar el hecho de que se alteren ligeramente las convenciones discursivas de lo que podría ser un discurso crítico-teórico al no ser identificada la fuente de estas citasalusiones. Si el estilo responde a esas propuestas del discurso teórico, la cita se camufla en el tejido textual como si se tratase de un poema que establece una conversación con otros textos sin necesidad de identificar el origen de esas citas. Todo lo contario sucede con esas otras citas que entrecruzan el texto e interrumpen la lectura: la de Nietzsche, que pertenece al fragmento 56 de El libro del filósofo, o la cita de Bretch. Esta doble manera de citar da buena cuenta del carácter anfibio de este texto que sutura los discursos teórico y poético creando una bisagra entre ambos.

${ }^{27}$ Véase el Cuerpo fragmentario o la alternancia del discurso propio y el ajeno en textos como «Prosa» (Talens, 1989: 197-199) o en textos contiguos como son «Acerca de la práctica I» $\rightarrow$ «Observaciones sobre el tema del crepúsculo» $\rightarrow$ «Acerca de la práctica II» en donde se alternan textos de Mao con los del propio Talens.
} 
Al margen de que existan evidentes lazos formales y estructurales entre los metapoemas y el resto de composiciones lo que interesa es subrayar la manera en que el discurso lírico se permeabiliza ante las maneras del discurso crítico. Las ideas acerca de la poesía (pérdida de la referencialidad — disminución semántica — y pérdida del carácter comunicativo — disminución pragmática-) constituyen un rasgo intencional que, de un lado, garantiza la unidad ideológica aun en la dispersión formal y, de otro, fuerza a que el lector construya en su recepción distintos niveles enunciativos. En los niveles superiores aparece un estrato fuertemente asimilado al discurso crítico y que puede relacionarse con aquellos actos de habla directivos ${ }^{28}$ o con las funciones de control, tal y como propone Gérard Genette (1989: 309). Aquí existe, o al menos el lector percibe, una intención comunicativa ${ }^{29}$. En los niveles inferiores se encuentran otros poemas que, al estar relacionados con los anteriores, acaban por poseer una fuerte carga metapoética. Sin embargo, el uso de un lenguaje simbólico los hace más fácilmente adscribibles al género lírico. De esta suerte puede afirmarse que existen al menos dos niveles enunciativos: una enunciación metapoética que regula y controla las condiciones de recepción de otra enunciación que podría denominarse poético simbólica.

La propuesta de distintos niveles pragmáticos surge así como una necesidad que el lector articula para solucionar la contradicción que puede ser la de intentar hablar de un lenguaje que nada comunica a través del propio lenguaje. En casos como el de Cernuda puede verse cómo su propia escritura llegaba incluso a condicionar la interpretación de otros escritores (Trabado Cabado, 2000). Aquí sucede lo contrario: la mediación teórica articula la escritura ${ }^{30}$.

\footnotetext{
${ }^{28}$ Searle propone una reordenación de los actos ilocutivos de Austin. Dentro de esta nueva taxonomía tienen cabida los actos de habla directivos: «su objeto ilocucionario consiste en el hecho de que son intentos (...) del hablante de lograr que el oyente haga algo» (1991: 460).

${ }^{29}$ Sobre el carácter intencional y comunicativo del metatexto puede leerse el trabajo de Jacques Dubois (1973). El carácter comunicativo es perceptible en determinados metapoemas en cuanto que son muestras de una intencionalidad destinada a crear las condiciones necesarias para una correcta lectura. Tengo en cuenta las precisiones del propio Talens, que afirma que la literatura no comunica sino que basa su actividad en la significación: «Luego yo a ese proceso por el cual, no eres tú quien me está comunicando, sino que es la imagen del texto, producida a partir del texto, quien me está comunicando, a eso es a lo que, en semiótica, se llama significación. De lo contrario, un escritor siempre sería consciente de lo que hace y no es verdad» (Talens, 1980: 239). Mi propuesta parte de pensar que en el metapoema en tanto que codificación a priori del resto de poemas es una muestra consciente del autor sobre el propio texto. Otra cosa, son el resto de poemas, que sí se basarían en la significación. Así, pues, podría establecerse una relación entre enunciación metapoética $\rightarrow$ comunicación y enunciación poético-simbólica $\rightarrow$ significación.

${ }^{30}$ Indudablemente estamos ante distintos cauces de representación del discurso crítico. En el caso de Cernuda convendría hablar del ensayo o de un tipo de crítica militante (Maristany, 1994 y Pozuelo Yvancos, 2009); para el caso de determinados metapoemas de J. Talens estamos ante un discurso con una apariencia visual (y aun esto es dudoso) que lo entronca con la lírica. A todo ello se puede decir:
} 
Esta dualidad enunciativa permite, además de evitar la contradicción anteriormente mencionada de hablar de la crisis del lenguaje, una mayor precisión a la hora de analizar dos hechos fundamentales en la poesía postmoderna: la polifonía y la intertextualidad.

Por un lado la polifonía puede verse como un objeto o tema de la propia poesía o como un procedimiento. De la misma manera ocurre con la intertextualidad: si de un lado sirve para afianzar la coherencia entre la poética y la poesía, de otro, sirve para reafirmar la pérdida del vínculo entre autor y texto para situar la relación entre texto y texto.

Otra función que desempeña la enunciación metapoética en Jenaro Talens es la de crear una distancia no sólo entre autor y texto sino entre texto y lector. Dominique Combe habla de una referencia desdoblada mediante la cual la poesía es capaz de transcender un discurso individual para, mediante una auto-alegorización del yo lírico, convertirse en un discurso universal. Todo ello gracias a la atenuación del factor contextual. Sin embargo, como ya he indicado estos metapoemas-prólogo constituyen una suerte de contexto, si bien ideológico, que forma una profunda barrera a la hora de una apropiación del

a) Que para algunos teóricos, caso — por ejemplo— de G. Hartman, la frontera entre creación y crítica es difusa.

b) Que la diferencia que se tiene en cuenta para hablar de lo ficticio o no ficticio del metatexto es de índole situacional: la crítica habla del texto; el metapoema de Talens habla en el propio texto. Al margen de que la metapoesía esté monopolizada por el autor mientras que la crítica se desenvuelve más en el terreno del lector, me interesa señalar dos casos: el de T. S. Eliot, que elimina fragmentos de su Waste Land por consejo de Pound pero que los suple con una serie de notas que funcionan a modo de guía, o el caso más reciente de Javier Marías, quien en su Negra espalda del tiempo propone un tipo de lectura determinada para Todas las almas. Sólo hay espacio para enunciar el problema, pero en todos estos casos se está dirigiendo una lectura mediante un proceso de transducción a través del cual el texto literario se transforma en texto crítico pero sin abandonar los supuestos límites de la propia literatura. Para comprobar la afinidad del pensamiento teórico-crítico de Talens con sus propuestas metapoéticas remito a la compilación de ensayos titulada El sujeto vacío (Talens, 2000). Me hago eco de unas palabras incluidas en el artículo «La construcción de la identidad» donde afirma: «El «yo» que comienza el relato es un signo vacío que se refiere a su propio discurso más que a cualquier otra realidad.» (Talens, 2000: 32). Cuando coexisten en la figura del escritor y del crítico se observa, como sería esperable dentro de un planteamiento coherente, un diálogo entre la escritura artística y el pensamiento crítico. Entre los muchos ejemplos posibles no quiero dejar de citar la obra del poeta y profesor Alfredo Saldaña que puede establecer ciertos parentescos con la de Jenaro Talens. Si recordamos unos versos suyos titulados «El texto del mundo» que dicen así: «Y después de haberlo escrito, / el mundo queda dispuesto para ser leído» (12) uno no puede dejar de pensar en su obra crítica titulada $E l$ texto del mundo. Crítica de la imaginación literaria. No sólo las relaciones se dan en el título sino que existen casos de trasvases de frases del poema al texto crítico. Así se inicia el poema titulado «Signos»: «Todo signo es un destino que ha de cumplirse, es la huella / de un futuro aún no escrito que el paso del tiempo permitirá leer» (Saldaña, 2003a:29). La misma frase se puede encontrar encabezando el epígrafe «Percepción y conocimiento» del libro ya mencionado (Saldaña, 2003b: 33). 
mensaje lírico. Se destruye allí la ilusión de un discurso emocional. La poesía se convierte en un teatro en donde el lenguaje entabla un diálogo consigo mismo. La poesía no comunica; no existe una alegorización del yo lírico sino una teatralización. Sin embargo, la condena del lenguaje es significar y mientras exista un lector capaz de avivar las cenizas del sentido estaremos destinados a entendernos o al menos a malinterpretarnos sobre la conjetura de las intenciones de la voz ajena.

$\mathrm{Si}$, como quería Platón, toda escritura se desenvuelve en un estado de orfandad; si la intemperie es su territorio primigenio y eso promueve que cada lector transite por ella a su gusto con la tentación de ensayar sentidos infinitos una vez constatada la ausencia definitiva del autor, la enunciación metapoética ofrece un pequeño mapa para realizar ese tránsito. No puede verse en modo alguno como una coerción sino como el resultado de la aparición en la poesía de un sustrato teórico que está vehiculado por una voz que pertenece al texto y, por tanto, es un artificio retórico pero que en esencia resulta cercana al pensamiento ético y teórico del autor real hasta el punto de poder ser asimilada a él. Esto explica la convergencia entre la obra crítica y la creación literaria. Existen, pues, territorios fronterizos entre la poesía y el pensamiento teórico y ése es el lugar de la enunciación metapoética, que al actuar provoca que el texto no sólo signifique sino que además comunique. Se establecen así unas coordenadas sobre las que asentar el discurso, un pacto si se quiere utilizar el término. Conlleva, además, que exista una suerte de estratificación textual en la que la metapoesía actúa a un nivel superior que el resto de poemas. Esto, además, permite la resolución de una paradoja: el metapoema puede declarar que el resto de poemas, al menos en el caso de la obra de Talens, tratan de una ausencia. Quien escribe ya no está, como quien cierra con llave la puerta y se va. La enunciación metapoética en Talens sirve para entender la realización paradójica de un lenguaje que habla sobre su incapacidad para decir a su autor, en definitiva, constata la presencia de una ausencia. 
APÉNDICE DE TEXTOS

\section{MÉTODO DEL DISCURSO}

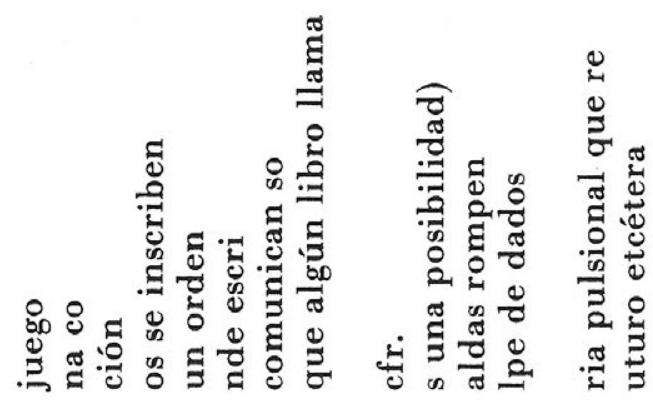

\section{«toda denominación es una tentativa de alcanzar la imagen» (Nietzshe)}

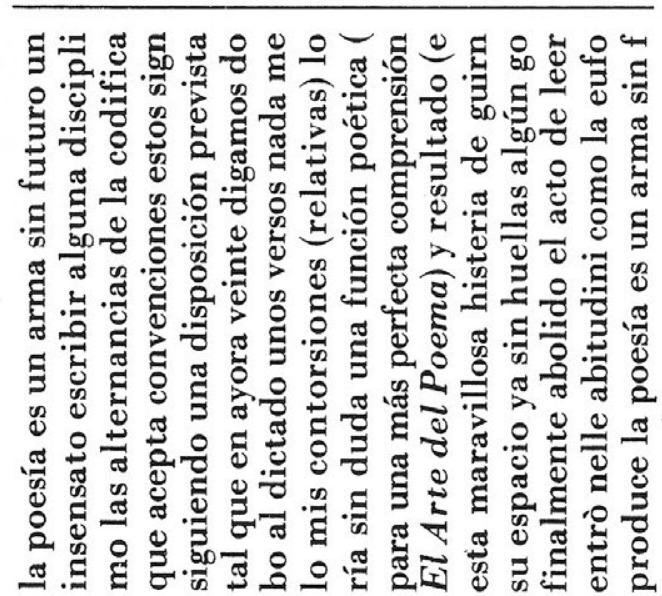

"todo el provecho que saco de mi tiempo lo debo a la confusión, pues de la claridad no se obtiene provecho alguno»

(B. Brecht)

Poema: "Método del discurso" que encabeza la sección "La máquina de significar" de $E l$ cuerpo fragmentario. Se toma de la compilación Cenizas del sentido. Poesía 1062-1975. Madrid: Cátedra, p. 193. 
EL ESPACIO DEL POEMA

Je ne crois pas au sublime ni à la
poésie mais à la nécessité.
ARTAUD

mente deben estar recitando en tendida proese instante, mientras otra figura parece querer evadirse de un lu. gar donde la mentira se hace es. pectáculo, la máscara, imagen de la verdad. O tal vez entra en él. El cuadro sólo deja ver su mano iz. quierda aferrada a los barrotes de una escalerilla y un rostro sin expresión (ni siquiera el esfuerzo físico deja ahí su huella). Sale o entra? El pintor no lo dice. Proba blemente nun lo dice. Probablemente nunca lo supo con certeza; de ahi la inexpresivid rostro. En la casucha se celebra un banquete. EI vino debe haber co. rrido en abundancia. Un hombre (chaquetilla verde, pantalón rojo) está tirado en el suelo, sobre la parte inferior derecha del cuadro. El resto de los comensales hace tiempo que olvidó las convenciotiempo que olvido las convenciones de qua tranquila reunión social. En posicion casi simetrica, en la esquina izquierda inferior (separado por un cuarteto de cocineros), otro grupo reproduce situación idéntica, pero al aire libre, sin las trabas del espacio cerrado de la habitación. Un grupo juega a dados. Tras ellos, varias figuras, caídas, luchan. Un brazo en alto y descamisado amenaza con gol. pear. Todos ellos compensan, respecto al eje central del tabanque, la otra lucha del margen derecho: puesta de poder: he ahí el aspecto externo de estos datos, lo que podríamos denominar su superficie (opaca, según se explica) en su doble vertiente: más tarde re flexión: des. cripción reflejada previo sometimiento al orden de un riel insobornable: benn dijo la sintaxis: la que presiente el juego amoroso sobre la mesa de las parejas (tocas blancas, vien-
tres abultados por las arrugas y la el libro: relavejez) enaltecidas por el banquete. tar su proceso:

La parte superior del cuadro (el fondo de la escena, dicen las leyes de la perspectiva) está integrada por numerosos grupos dispersos, cuyo exiguo tamaño (también impuesto por la perspectiva) no im-
pide la función simbólica de su pide la función simbólica de su comportamiento en la ficticia rea-
lidad de la pintura. Antes bien, la hace patente, y, más, la multipli. ca. Pues algo les hace diferentes a sus compañeros de la mitad inferior. La inexpresividad ha dado paso a una aupresidad ha dado paso a una ausencia de rostro. Son sólo cuerpos, miembros que un trazo asume sin especificar, gestos cuyo movimiento borra toda señal de identidad. Cuerpos anónimos dando curso efectivo a lo que, sin duda, constituye la vida a su alrededor. Una vida separada, definitivamente ya, de los concretos in dividuos que a diario aparentan (deI otro lado de la tela) ser su (der otro lisor. Tras su centro enisor. Tras su inidentidad sólo las superficies significan: curas, caballos, campesinos. Un pecador que, misteriosamente arrepentido (¿de qué pecado, pues?), simula la comedia de su confesión. (El rojo de su traje - el torpeza el te-

Fragmento del poema "El espacio del poema" incluido como prólogo al libro El vuelo excede el ala. Se toma de la compilación Cenizas del sentido. Poesía 1962-1975. Madrid: Cátedra, 1989, pp. 13-15. 


\section{BIBLIOGRAFÍA CITADA}

Bagué Quílez, Luis (2006). Poesía en pie de paz. Modos del compromiso hacia el tercer milenio. Valencia: Pre-Textos.

Bagué Quílez, Luis y Susana Rodríguez Rosique (2013). «La ironía en segundo grado: (in)versiones discursivas en la poesía reciente», Bulletin of Hispanic Studies. 90.3, pp. 295-303. doi:10.3828/bhs.2013.20

Bajtin, Mijail (1989). Teoría y estética de la novela. Madrid: Taurus.

Ballart, Pere (1994). Eironeia. La figuración irónica en el discurso literario moderno. Barcelona: Sirmio. Quaderns Crema.

Barthes, Roland (1987). «La muerte del autor.»El susurro del lenguaje. Más allá de la palabra y la escritura. Barcelona: Paidós, 1987. 65-71.

Barthes, Roland (1997). S/Z. Buenos Aires: Siglo XXI.

Blesa, Tua. (1987). «El laberinto de los espejos», Tropelías. 1, pp. 43-63.

Carnero, Guillermo (1987). Dibujo de la Muerte. Obra poética. Ignacio Javier López (ed). Madrid: Cátedra.

Casas, Ana (ed.) (2012). La autoficción. Reflexiones teóricas. Madrid: Arco Libros.

Casas, Arturo (1994). «Pragmática y lírica», en Darío Villanueva (ed.), Avances en la Teoría de la Literatura. Santiago de Compostela: Universidad de Santiago, pp. 229-308.

Combe, Dominique (1996). «La référence dédoublée: le sujet lyrique entre fiction et autobiographie», en Dominique Rabaté (ed.), Figures du sujet lyrique. París: Presses Universtaires de France, pp. 37-63.

Díaz, Susana (2006). El desorden de lo visible. Introducción a la poética de Jenaro Talens. Madrid. Biblioteca Nueva.

Dubois, Jacques (1973). «Code, texte, metatexte», Littérature 12, pp. 3-11.

Falcó, José Luis (2007). «"Salmo dominical": Escenificación de la mirada y el "Yo-lenguaje". Hacia una lectura de la "Poética" de Jenaro Talens», en Juan Carlos Fernández Serrato (ed.), Mi oficio es la extrañeza. Ensayos sobre la poesía de Jenaro Talens. Madrid: Biblioteca Nueva, pp. 122-136.

Galí, Neus (1999). Poesía silenciosa, pintura que habla. Barcelona: El Acantilado.

Gamoneda, Antonio (2002). «Poesía y literatura: ¿límites?», en José Enrique Martínez Fernández (ed.), Estudios sobre literatura comparada. León: Universidad, pp. 33-42.

García Berrio, Antonio (1975). Introducción a la poética clasicista: Cascales. Barcelona: Planeta.

Genette, Gérard (1989). Figuras III. Barcelona: Lumen.

Genette, Gérard (1993). Ficción y dicción. Barcelona: Lumen.

Guerrero, Gustavo (1995). El género lírico en el Renacimiento. Valencia: Eutopía.

Guerrero, Gustavo (1998). Teorías de la lírica. México: Fondo de Cultura Económica.

Gutiérrez Ordóñez, Salvador (1996). Introducción a la semántica funcional. Madrid: Síntesis.

Jiménez Arribas, Carlos (2007). «Jenaro Talens: la práctica metapoética del poema en prosa», en Juan Carlos Fernández Serrato (ed.), Mi oficio es la extrañeza. Ensayos sobre la poesía de Jenaro Talens. Madrid: Biblioteca Nueva, pp. 172-233.

Kruger-Robbins, Jill (1997). Frames of Referents. The Postmodern Poetry of Guillermo Carnero. Lewisburg: Bucknell University Press.

Langbaum, Robert (1996). La poesía de la experiencia. El monólogo dramático en la tradición literaria moderna. Prólogo de Álvaro Salvador. Granada: Comares.

Lanz, Juan José (1994). La llama en el laberinto. Poesía y poética en la Generación del 68. Mérida: Editora Regional de Extremadura.

Lázaro Carreter, Fernando (1990a). «El poema y el lector (El poema como signo)», en De poética y poéticas. Madrid: Cátedra, pp. 15-33. 
Lázaro Carreter, Fernando (1990b). «El poeta y el lector», en De poética y poéticas. Madrid: Cátedra, pp. 34-51.

López, Ignacio Javier (1986). «Metonimia y negación: Variaciones y figuras sobre un tema de la Bruyère de Guillermo Carnero», Hispanic Review. 54/3, pp. 257-275.

Lozano, Joaquín, Carmen Peña y Gonzalo Abril (1982). Análisis del discurso. Hacia una semiótica de la interacción textual. Madrid: Cátedra, 1982.

Luján Atienza, Ángel Luis (2005). Pragmática del discurso lírico. Madrid: Arco Libros.

Lucifora, María Clara (2013). «"Palabras escritas con orgullo". Autoficción y compromiso en "Vista cansada" de Luis García Montero», Tropelías. 19, pp. 319-344.

Maestro, Jesús G. (2006). El concepto de ficción en la literatura (Desde el Materialismo filosófico como Teoría Literaria Contemporánea). Pontevedra: Mirabel Editorial.

Maristany, Luis (1994). «El ensayo literario de Luis Cernuda», en Luis Cernuda, Prosa I. Madrid: Siruela, pp. 17-63.

Martín-Estudillo, Luis (2007). La mirada elíptica: el transfondo barroco de la poesía española contemporánea. Madrid: Visor.

Martínez Fernández, José Enrique (2001). La intertextualidad literaria (Base teórica y práctica textual). Madrid: Cátedra.

Navarro, Desiderio (ed.) (1997). Intertextualité. Francia en el origen de un término y el desarrollo de un concepto. La Habana: Casa de las Américas / Embajada de Francia en Cuba.

Oomen, Ursula (1986). «Sobre algunos elementos de la comunicación poética», en José Antonio Mayoral (ed.), Pragmática de la comunicación literaria. Madrid: Arco Libros, pp. 137-149.

Pérez Parejo, Ramón (2002). Metapoesía y crítica del lenguaje (De la generación de los 50 a los novísimos). Cáceres: Universidad de Extremadura.

Pérez Parejo, Ramón (2007). Metapoesía y ficción: claves de una renovación poética (Generación de los 50. Novísimos), Madrid: Visor.

Picchione, John (2004). The New Avant-Garde in Italy. Theoretical Debate and Poetic Practices. Toronto / Buffalo / Londres: University of Toronto Press.

Piera, Carlos (1995). «Yo, literalmente», Archipiélago. 23, pp. 34-41.

Pilkington, Adrian (2000). Poetics Effects. A Relevant Theory Perspective. Ámsterdam / Philadelphia: John Benjamins Publising Company.

Pozuelo Yvancos, José María (1994). Teoría del lenguaje literario. Madrid: Cátedra.

Pozuelo Yvancos, José María (1998). «¿Enunciación lírica», en Germán Gullón y Fernando Cabo Aseguinolaza (ed.), Teoría del poema: La Enunciación Lírica. Amsterdam / Atlanta: Rodopi, pp. 41-78.

Pozuelo Yvancos, José María (1999). «Pragmática, poesía y metapoesía en el «Poeta» de Vicente Aleixandre», en Fernando Cabo Aseguinolaza (ed.), Teorías sobre la lírica. Madrid: Arco Libros, pp. 177-201.

Pozuelo Yvancos, José María (2007). «El sujeto vacío en el Taller poético de Jenaro Talens», en Juan Carlos Fernández Serrato (ed.), El techo es la intemperie. Poesía y poética en Jenaro Talens. Madrid: Visor, pp. 209-225.

Pozuelo Yvancos, José María (2009), «La crítica literaria de Luis Cernuda», Poéticas de poetas. Teoría, crítica y poesía. Madrid: Biblioteca Nueva, pp.163-178.

Pozuelo Yvancos, José María (2010). Figuraciones del yo en la narrativa. Javier Marías y E. Vila-Matas. Valladolid: Cátedra Miguel Delibes.

Prieto de Paula, Ángel Luis (1996). Musa del 68. Claves de una generación poética. Madrid: Hiperión.

Rabaté, Dominique (1996). «Énonciation poétique, énonciation lyrique», en Dominique Rabaté (ed.), Figures du sujet lyrique. París: Presses Universitaires de France, pp. 65-79.

Rodríguez Rosique, Susana y Luis Bagué (2012). «Verso y reverso: teoría pragmática de la ironía y el humor en la poesía española contemporánea», Bulletin Hispanique. 114.1, pp. 411-438. 
Saldaña, Alfredo (1997). Modernidad y postmodernidad. Filosofía de la cultura y teoría estética. Valencia: Episteme.

Saldaña, Alfredo (2003a). Pasar de largo. Zaragoza: Prensas Universitarias de Zaragoza.

Saldaña, Alfredo (2003b). El texto del mundo. Crítica de la imaginación literaria. Zaragoza: Colección Trópica. Anexos de Tropelías 11.

Sánchez Torre, Leopoldo (1993). La poesía en el espejo del poema. La práctica metapoética española del siglo XX. Oviedo: Universidad.

Scarano, Laura (2004). Las palabras preguntan por su casa. La poesía de Luis García Montero. Madrid: Visor.

Searle, John. (1991). «Una taxonomía de los actos ilocucionarios», en Luis M. Valdés Villanueva (ed.), La búsqueda del significado. Madrid: Tecnos, Universidad de Murcia, pp. 449-476.

Smilek, Ewa (2013). Espacio de transformación. (Meta)poesía de Jenaro Talens: entre teoría y práctica [Tesis de doctorado en línea]. Sosnowiec: Universidad de Silesia, disponible en http://www.sbc.org.pl/Content/88097/doktorat3418.pdf [ref. de 10/03/2014].

Sperber, Dan y Deirde Wilson (1994). La relevancia. Madrid: Visor, 1994.

Talens, Jenaro (1977). La escritura como teatralidad. Valencia: Universidad de Valencia.

Talens, Jenaro (1980). «Práctica crítica y reflexión metapoética», en Teorías semiológicas aplicadas a textos españoles. Groningen: Universidad, 1980, pp. 229-241.

Talens, Jenaro (1989). Cenizas del sentido. Madrid: Cátedra.

Talens, Jenaro (2000). El sujeto vacío. Cultura y poesía en el territorio Babel. Madrid: Cátedra / Universitat de Valencia.

Talens, Jenaro (2002). Negociaciones para una poética dialógica. Madrid: Biblioteca Nueva.

Talens, Jenaro (2002). Cantos rodados (Antología poética, 1960-2001). Juan Carlos Fernández Serrato (ed.). Madrid: Cátedra.

Trabado Cabado, José Manuel (2000). «Hermenéutica y sobreinterpretación. Notas sobre la crítica literaria de Cernuda», en Antonio Sánchez Trigueros, María Ángeles Grande Rosales y María José Sánchez Montes (ed.), Miradas y Voces de Fin de Siglo. Actas del VIII Congreso Internacional de la Asociación Española de Semiótica, vol. II. Granada: Asociación Española de Semiótica, pp. 953-963.

Trabado Cabado, José Manuel (2002). La lectura lírica. Asedios pragmáticos a textos poéticos. León: Universidad de León.

Trabado Cabado, José Manuel (2007). «La desfiguración del sujeto lírico: traducción, máscara y escritura teatralizada», en Juan Carlos Fernández Serrato (ed.), Mi oficio es la extrañeza. Ensayos sobre la poesía de Jenaro Talens. Madrid: Biblioteca Nueva, pp. 43-54.

Fecha de recepción: 11 de marzo de 2014.

Fecha de aceptación: 23 de julio de 2014. 